\title{
The Analysis of Indonesia Cultural Diplomacy Through Angklung In Strengthening National Identity
}

\author{
Stanijuanita Marantika ${ }^{1}$,Izza Firdausi ${ }^{2}$, Zein Nidaulhaq Firdaus ${ }^{3}$, Rifqah Sajidah $^{4}$
}

\begin{abstract}
Indonesia is the multicultural country. There are many differences and diversity that Indonesia has as language, race, tribe, religion even culture. Instead of becoming Indonesia heritage, it also becomes crack for the unity if the governance cannot supervise it with well maintain. One of the examples is Angklung that was ever claimed by Malaysia. It gives a lot of protests from Indonesia citizens and evaluation for Indonesia to maintain more the culture that Indonesia has. That moment proves how valuable Angklung is. According to Unesco, Angklung is an Indonesian musical instrument consisting of two to four bamboo tubes suspended in a bamboo frame, bound with rattan cords. The purpose of this research is to identify how Angklung can be one of soft power that strengthens national identity Indonesia. Study literature and interviews were used to collect data about this research. Then explains and describes the efforts made by the government as a form of cultural diplomacy to promote Indonesia to the world through Angklung.
\end{abstract}

Keywords - Angklung, Art, Cultural Diplomacy, Indonesia, National Identity.

\section{INTRODUCTION}

The Indonesian archipelago is the richness of culture, has population 243 million and the area is 1.9 million sq $\mathrm{km}$ (742,308 sq miles), major languages Indonesia is Indonesian while there are a lot local languages, race, tribe religion even culture. Then angklung is one the wonderful heritage that Indonesia has. Angklung initially emerged as a form of religious ritual. Its main function is to invite Dewi Sri, the Goddess of Rice to come to earth to give a blessing on the earth and fertility fot the plants. While the forms of angklung has a philosophy where each tube is likened to a man's relationship with other humans. Different size of each tube means that everyone has a different way to create harmony in the world. The word Angklung originated from two words angka and lung. Angka means "tone", and lung means "broken" or "lost". Angklung then means as an incomplete tone [1].

According to experts, the traditional music of the Universitas of Pasundan (Unpas) Rosikin in Bandung, although angklung is a traditional music instrument because of the flexiblity music instrument it can follow the development of the world. Angklung has a dual function, first the pentatonic music is the original tone of the Sundanese songs

Stanijuanita Marantika ${ }^{1}$,Izza Firdausi ${ }^{2}$, Zein Nidaulhaq Firdaus ${ }^{3}$, Rifq Sajidah4Universitas Padjadjaran ${ }^{2}$, Universitas Padjadjaran, Universitas Padjadjaran $^{4}$ but can also be developed with diatonic music that is widely used by Western music. In addition to flexible, angklung is also a means of traditional music which is very easy to play. For those who never learn angklung, can immediately understand how to play it in just a few minutes. Amazingly one person can play at the same pitch four octaves.

The oldest angklung still exist is called Angklung Gubrag. The angklung was made in the 17th century in Jasinga, Bogor. Nowadays, some of reviews those older Angklung Werner in Sri Bduga Museum, Bandung [2]. Then in 1938, Daeng Soetigna make diatonic tones of angklung more often used to play with western songs rather than traditional tones. Since that time the angklung is used for education and entertainment. The first time, angklung performances get the world's attention is when the Asia Africa Conference in the year 1955. Following the struggle Daeng Seotigna, her student Udjo's wife, collaborated with her husband thereby opening the House of Angklung or Saung Angklung -as we called it- in Bandung.

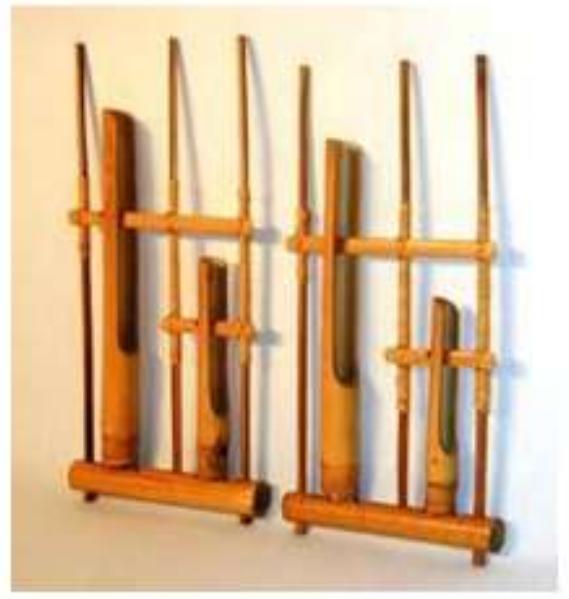

Fig.1: Angklung(mannaismayaadventure.com,2011) 


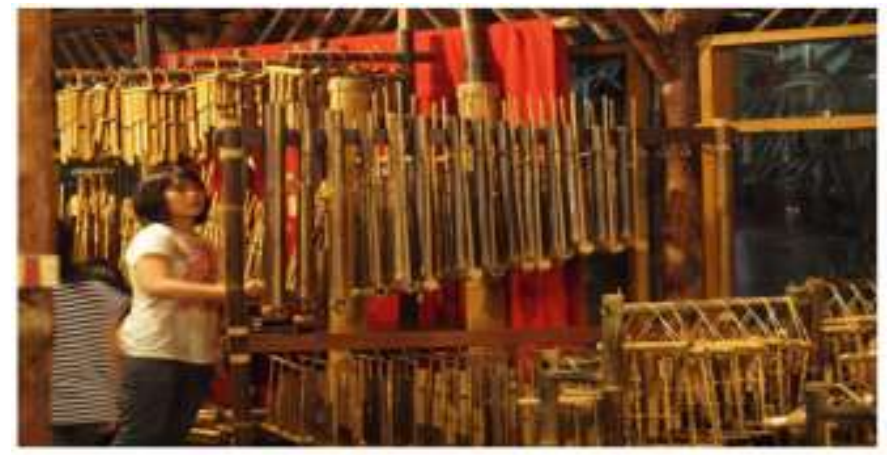

Pic.1: The Types of Angklung(mannaismayaadventure.com,2011)

Every year angklung join international festival and do some performance abroad. For example, The Indonesian Consulate in Vancouver held Asian Studies Day held in Langara College, Vancouver, February 7th, 2017 to promote good relation between Indonesia and Canada [3]. One of the culture that the Indonesian Consulate displayed is an angklung musical instrument. Then in the Nairobi, the Indonesian Embassy gave a general lecture about Indonesia and Introduced angklung to the students at the University of Eastern Africa of the West on, about a six-hour to promote Indonesia culture [4]. House of angklung Udjo set the new world record in Beijing for The Largest angklung Ensemble in 2013. Before that, it had already set the world record angklung ensemble in Washington DC, USA, in 2011. Thousands of people from different nationalities and cultural backgrounds together swayed made of bamboo instruments and melodious music [5].

In 2015, the new world record was created during the 60th Asian African Conference Commemoration (AACC), 20.000 people playing angklung, with theme 'The Angklung Harmony for the World' at Siliwangi Stadium in Bandung, West Java, Indonesia [6]. So that angklung will attract world's attention. Embassy of the Republic of Indonesia Bangkok in collaboration with Indonesian Women's Association (Dharma Wanita Persatuan or DWP) of the Ministry of Public Works (PU) of Indonesia Bandung presented a cultural show "Indonesian Angklung Night" at The Siam Society Under Royal Patronage, Bangkok, on Tuesday, 12th March 2013, at 6 pm - 8.30 pm. On Friday, May 27, 2011 at the Vanuatu Cultural Center a closing ceremony was held for the 8-day [7].

\section{UNDERSTANDING CULTURAL DIPLOMACY}

As Dizard points out, public diplomacy tends to focus on promoting the ideas and values of one society to another through cultural programs and information. However, cultural diplomacy is not driven solely by the idealism of mutual understanding. A new development is reflective of shifts in cultural policy toward conceiving culture as a resource [8].It is about activity to promote and introduce a culture one country, one nation, to support foreign policy or goals of its diplomacy, according to Simon Mark (2009) in his paper 'A Greater Role for Cultural Diplomacy'. The role of actor, government who involved, the propose to set, tha activity and the audience/targets are aspects that contribute to build the culturaldiplomacy. Mark explain that cultural diplomacy is similar with public diplomacy in how it works by the state. How the culture assist the operation of the state to combat stereotyping, increase mutual understanding and develop national image \& reputation, to cross the border of relationship. That seems as state's ability to attract the international attention and ensure another party to has a same principe or decision as the country who has soft power elements [9].

\section{METHODOLOGY}

The study of the Analysis of Indonesia Cultural Diplomacy Through Angklung In Strengthening National Identity is carried out with the following step: first, collect data about angklung and how angklung works as cultural diplomacy. Second, collect the data about the correlation between cultural diplomacy and strengthening national identity.

\section{NATIONAL IDENTITY}

National identity from a geographic perspective, where spaces of power and identity meet, where societies ascribe political significance to places, and nations are built in order that people develop emotional bonds to places [10]. Cultural diplomacy is closely related to national identity. The culture that used to be cultural diplomacy contain a value that state hold as a principle as a national identity. A culture that used to promote and to introduce has a typical value as state concerned.

The culture directly or indirectly can influence the perspective mind-set another state. Cultural diplomacy is a new concept in international relations while it has been oldphenomenon. In 2010, Angklung is admitted by UNESCO as world heritage [11]. Indonesia government try to promote angklung in every international event so that other country, foreigner know that there is a country that named Indonesia and has unique culture to introduce and give the 'brand' for Indonesia. As well-known angklung will make Indonesia has higher power bargaining towards other country and make others guess what kind of Indonesia as a state.

\section{V.CONCLUSION}

Angklung is traditional-instrument music that used to be the way Indonesia to promote and introduce the country as form as cultural diplomacy. By displaying angklung ini many international events support Indonesia indirectly to introduce what kind of Indonesia itself. Then used that culture to make further relation towards other country and influence the value tha Indonesia hold as principe.

\section{REFERENCES}

[1] Mannaismayaadventure (2011, January 01). History of Angklung (Indonesian Traditional Music Instrument). Retrieved $27^{\text {th }}$ of February, 2017, from Web: http:// mannaismayaadventure.com/2011/01/01/history-of-angklungindonesian-traditional-music-instrument

[2] Mannaismayaadventure (2011, January 01). History of Angklung (Indonesian Traditional Music Instrument). Retrieved $27^{\text {th }}$ of February, 2017, from Web: http:// 
mannaismayaadventure.com/2011/01/01/history-of-angklung-

indonesian-traditional-music-instrument

[3] Ministry Foreign Affairs (2017, February 08). Engaging the Academic Community With Angklung and Cassava Chips 80 . Retrieved $27^{\text {th }}$ of February, 2017, from webhttp://www.kemlu.go.id/en/berita/beritaperwakilan/Pages/Engaging\%20Academic\%20Community\%20With\%2 0Angklung\%20and\%20Casava\%20Chips.aspx

[4] Ministry Foreign Affairs (2016, April 9). The Sound of Angklung in Kenya. Retrieved $27^{\text {th }}$ of February, 2017, from Web: https:// http://kemlu.go.id/nairobi/lc/berita-agenda/berita-perwakilan/Pages/TheSound-of-Angklung-in-Kenya.aspx

[5] A P Dewi (2014, November). Saung Angklung Udjo, Swing Your Angklung!Retrieved $\quad 27^{\text {th }} \quad$ of February, 2017, from Webhttp://www.kemlu.go.id/Majalah/Indoinvites\%20II.pdf

[6] Jakarta Post(2015,April 23). Bandung breaks 'angklung' world record. Retrieved $27^{\text {th }}$ of February, 2017, from Web: http://www.thejakartapost.com/news/2015/04/23/bandung-breaksangklung-world-record.html

[7] Ministry Foreign Affairs (2013, March) 13. Cultural Diplomacy: Indonesian Angklung Hypnotized Bangkok. Retrieved 27 ${ }^{\text {th }}$ of February, 2017, from Web: http://www.kemlu.go.id/en/berita/beritaperwakilan/Pages/Cultural-Diplomacy-Indonesian-AngklungHypnotized-Bangkok.aspx

[8] TAE YOUNG KIM and DAL YONG JIN. (2015, Nove,ber 29).Cultural Policy in the Korean Wave: An Analysis of Cultural Diplomacy Embedded in Presidential Speeches. Retrieved $27^{\text {th }}$ of February, 2017, Webhttp://ijoc.org/index.php/ijoc/article/viewFile/5128/1838

[9] Norrman, Karl-Erik. 2013. Definitions, Ideas, Visions and Challenges for Cultural Diplomacy. Retrieved $26^{\text {th }}$ of FebruaryE-International Relations Website. URL: http://www.e-ir.info/2013/01/03/definitionsideas-visions-and-challenges-for-cultural-diplomacy/

[10] Mark, Simon. 2009. A Greater Role for Cultural Diplomacy. Discussion Papers in Diplomacy.

[11] Netherlands Institute of International Relations 'Clingendael'. ISSN 1569-2981

[12] Margaret Keane.NATIONAL IDENTITY: Conceptual Framework. Retrieved $27^{\text {th }}$ of February, 2017, from Web: http://cgge.aag.org/NationalIdentity1e/ConceptualFramework_Oct09/ind ex.html

[13] UNESCO (2009). Culture. Retrieved $27^{\text {th }}$ of February, 2017, from Web:http://www.unesco.org/archives/multimedia/?pg=33\&s=films_deta ils\&id=1681 